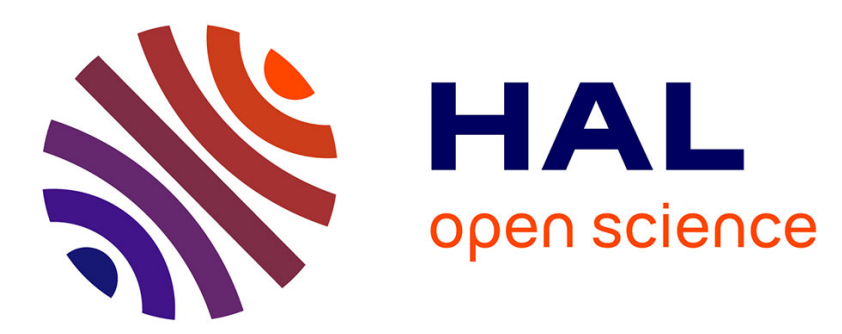

\title{
The Co-production of Science and Waterscapes: the Case of the Seine and the Rhône Rivers, France
}

\author{
Gabrielle Bouleau
}

\section{To cite this version:}

Gabrielle Bouleau. The Co-production of Science and Waterscapes: the Case of the Seine and the Rhône Rivers, France. Geoforum, 2014, 57, pp.248-257. 10.1016/j.geoforum.2013.01.009 . hal01085989

\section{HAL Id: hal-01085989 \\ https://hal.science/hal-01085989}

Submitted on 21 Nov 2014

HAL is a multi-disciplinary open access archive for the deposit and dissemination of scientific research documents, whether they are published or not. The documents may come from teaching and research institutions in France or abroad, or from public or private research centers.
L'archive ouverte pluridisciplinaire HAL, est destinée au dépôt et à la diffusion de documents scientifiques de niveau recherche, publiés ou non, émanant des établissements d'enseignement et de recherche français ou étrangers, des laboratoires publics ou privés. 


\section{The Co-production of Science and Waterscapes: the Case of the Seine and the Rhône}

\section{Rivers, France}

\section{Bouleau, G., IRSTEA BORDEAUX UR ETBX FRA}

\section{Introduction}

During the 1980s and 1990s, freshwater science developed based on the Seine and Rhône Rivers in different ways. In each river basin, a different set of scientists contributed to redefining what deserved public attention and investment. The Seine River was conceptualised as a series of spatially dispersed bioreactors: in each section, the temperature and chemical composition were understood to control bacteria, algae, and zooplankton development. This conceptualisation underpinned decisions about where the authorities should invest to reduce nitrogen and phosphorous inputs into the river. In contrast, the Rhône River was understood as a hydrosystem, whose fluvial geomorphology controlled the connections between habitats, which in turn determined floodplain biodiversity. This differing conceptualisation formed the basis of the quantification of instream flows downstream from hydropower facilities. Despite the converging endeavours of the French central state and European Union regulations to harmonise water allocation and management policies, both river basin authorities still refer to these distinct scientific representations to argue what the Rhône and the Seine Rivers should look like. Why is it that physical geography and plant ecology are considered so important in managing water in the Rhône valley, but are not taken into account in the Seine River basin? Why do water managers in Paris make decisions based on chemical and microbiological data, but not in Lyon?

In this paper, I argue that, before each model was conceived, specific circumstances challenged the institutional water management in both river basins, raising problems that were place-specific and had never before been addressed. New actors and scientists found 
opportunities in such situations for co-producing science and social order (Jasanoff, 2004), with the aim of addressing the issues at the river basin level. I suggest that the two distinct models reflect the resulting social orders which have ranked stakes, actors, and scientific disciplines according new criteria of relevance.

I outline both stories of co-production from the perspective of the scientists, focusing on their motives to engage with one river and not with the other. Based on thirty-three semistructured interviews, publications, and personal archives of scientists and water managers, I trace how some scientists made sense of the changing circumstances in these rivers in terms of opportunities for their research. I argue that their discipline and their other social commitments influenced their choices. Elaborating on Kuhn's definition of "normal science" as a "puzzle-solving" activity (Kuhn, 1963) and on Rose's definition of landscapes as labyrinths (Rose, 2002), I explore the scientific puzzles that were conceivable in both waterscapes, and how it oriented the co-production of science and social order.

My analysis of the Rhône and the Seine rivers draws on recent work combining political ecologies of water and social studies of science. Following Swyngedouw's (1999) perspective on water, I try to "overcome the dualisms of the nature/society divide" (:445) in order to focus on the 'socionatures' that constitute rivers, and which were historically produced by networks of humans and non-humans (Latour, 1993). I seek to avoid presenting such socionatures whether they are waste water bacteria or hydropower dams - as being more stable than they really are. The concept of the 'hydrosocial cycle' (Bakker, 2003a; Bakker, 2003b; Budds, 2008, 2009; Kaika, 2005) “describes the process by which flows of water reflect human affairs and human affairs are enlivened by water" (Linton, 2010:68). It allows me to account for the dynamic and internal processes through which water-related socionatures are continuously reworked as water flows and uses evolve. This concept highlights the material and ideological circumstances that allowed some water scientists and managers to produce 
water-related concepts and categories that they later heralded as universal. In this paper, I take these systematic representations of waterscapes as "the starting point for undertaking the archaeology of [their] socionatural metabolism" (Swyngedouw, 1999:448).

In the first section, I develop an analytical framework to account for the relations between socionatures in a waterscape, and the categories set up to understand and manage this waterscape. I then summarise how river basin authorities à la française came into being, without changing either the social order or producing new water science, but setting the waterscape for the events that were to follow. The third section examines the importance of the place where the Rhône 'hydrosystem' concept was created, and the way in which it was applied. I then expand on the contrasting progression of science and management with respect to the Seine River which was represented as a series of bioreactors. In the fifth section, I discuss the mutual framings of waterscapes and water science. I conclude by stressing the relevance of the hydrosocial cycle concept in understanding the dialectical relationships between categories describing certain waterscapes and these waterscapes.

1. The hydrosocial cycle and the dialectical production of water science

The hydrosocial cycle concept draws on recent work combining water political ecology and social studies of science (Budds, 2008, 2009; Kaika, 2005; Linton, 2008, 2010; Swyngedouw, 2004). It defines water as relational: social and natural, material and discursive. It departs from positivist and relativist approaches to water. It considers that water is not governed by universal natural laws nor is it purely shaped by external social relations of power. It should rather be understood as a historical hybrid, continuously affected by internal socio-ecological processes, which recycle material and discursive elements dialectically into new combinations of socionatures (Linton et al, this issue). In this perspective, ideas about water are "moments in a relational-dialectical scheme" (Linton, 2010:31). What Swyngedouw previously referred to as "waterscapes" (Swyngedouw, 1999) are the geographical temporary 
outcomes of these processes. Such moments and temporary geographies are not determined by forces, nor fixed characteristics of things; their possibilities are nevertheless constrained by the circumstances of practical experience.

1.1. Re-opening and closing off of the ontological question of what water is

Adopting this perspective, Linton calls for an "analytical hydrolectics", that is "to apply a relational-dialectical approach to the story of water and people" (:241). He analyses for instance the hydrologic cycle as a modern construction, dialectically produced by specific physical conditions and social projects. The hydrologic cycle owed much to Western twentieth century hydrologists' endeavours to establish their discipline as a distinct one (2010:126-147). Their modern account of water was constructed in northern temperate areas where there were "copious volumes of liquid surface water" (:123), a situation that made water easy to meter and divert. Elaborating on the concept of co-production of science and social order (Jasanoff, 2004), Linton further argues that modern states and modern hydrology mutually reinforced each other, since dam and canal projects of the former required quantification from the latter (:149). The hydrologic focus on surface water built a standpoint from which one could take stock of water and design water management systems. From this standpoint aridity was a problem, one that modern states were eager to address, for example in the United States (Espeland, 1998; Worster, 1992), in France (Trottier and Fernandez, 2010), and in Israel (Alatout, 2008), to cite only few. In such situations, the universality of the hydrologic cycle went unquestioned as its dismissal would have entailed political consequences. Linton encourages us to situate the circumstances under which water came to be managed in systems.

Systems are bounded, whereas a relational account of water implies no closure and keeps open the ontological question of what water is. To describe the co-production of specific water systems, one needs to start the story from somewhere. Different accounts are therefore 
possible. "In sum, water embodies multiple tales of socionature as hybrid" (Swyngedouw, 1999:446). One useful way to start with the archaeology of water-related ideas is to understand how the ontological question about water was reopened at one point and closed off somehow differently, and how it allowed the definition of new research problems and new bounded management systems.

\subsection{Shaping a puzzle in a waterscape}

I am interested in how scientists perceived what Linton conceptualises as "moments in a relational-dialectical scheme". How did they make sense of the situation, given their possible role (Goffman, 1967) as scientists trained in a specific discipline and as future experts advising water managers? What were the cognitive frames (Goffman, 1974) they referred to when gauging the risk of carrying out research on a river? Kuhn (1963) has argued that "one of the things a scientific community acquires with a paradigm is a criterion for choosing problems that, while the paradigm is taken for granted, can be assumed to have solutions" (:37). In dialectical terms, as the river flows, both reflecting and enlivening human affairs, scientists may or may not find opportunities for "puzzle-solving". A scientific puzzle may promise to resolve a water management problem, or may instead raise new management problems. Funding opportunities could be different in both situations.

When putting theory into practice, scientists need to categorise the waterscape into the abstract entities their paradigm requires. For instance, economists are likely to read the waterscape in terms of supply and demand of something; sociologists may seek social facts; ecologists may go into the field to identify gradients... Abstract categories are not directly readable in the waterscape, they require a 'reader'. In Rose's terms (Rose, 2002:455), which are consistent with the relational-dialectical scheme, "the landscape comes to appear in the world as it is put to task". Scientific categories result from confrontation and adjustment of 
theoretical puzzle templates to different ways of separating or grouping elements of the waterscape.

Scientists produce truth claims which reuse some categories while creating and publicising others. As Linton has shown for the institutionalisation of the hydrologic cycle, some categories and processes are more likely to be normalised as universal than others, based on their political importance. Institutions are interested in what scientists consider natural, since institutions tend to naturalise the categories they use to justify the social order on which they depend (Douglas, 1986). Scientists are thus likely to negotiate the relevant categories, in the process of co-production of science and social order (Jasanoff, 2004). For example, Thompson (2004) has shown that when geneticists produced evidence of an "African Elephant" paved the way for African Nations to establish different regional regimes of protection and hunting, because they argued that the population was to be assessed on a continental scale (Thompson, 2004).

Categorising requires the commensuration of socionatures whose historical circumstances of production are erased (Espeland, 1998). In trying to achieve generality, western logical methods have preferred the epistemological rule of Ockham's razor (Desrosières, 1998:69; Rodríguez-Fernández, 1999), which recommends using as few abstract entities as possible. This rule has been applied to categories of description. Large categories encompassing many objects or cases are supposedly more universal. However, they obscure distinct minorities of what they represent, as Haraway (1990) argues: "the category "woman" negated all nonwhite women; "black" negated all nonblack people, as well as black women..." (Haraway, 1990:197). In geographical terms, discarding the historical circumstances which have shaped specific places is not politically neutral, since political action is intrinsically attached to these places (Agnew, 1987; Gille, 2006; Steinberg and Clark, 1999; Taylor, 1999). The 
transformation of "humanised places" into "abstract spaces" can be "politically disabling" (Taylor, 1999:10-11).

In the process of co-production of science and social order, some scientific categories are likely to be reused by political actors more than others. Such scientific and political categories and the correspondent scientific puzzle they allow to shape may result in a "solution" describing what the waterscape should be. Jasanoff has argued that "representations of the natural world attain stability and persuasive power, in [her] view, not through forcible detachment from context, but through constant, mutually sustaining interactions between our senses of the is and the ought: of how things are and how they should be" (Jasanoff, 2010:236). A new understanding of what the waterscape should be is therefore a vehicle for institutionalising a new water management system. In this process, the ontological question of what water is may be closed off again, until new circumstances challenge institutional water management. This understanding of the co-production of water science and waterscapes within a dialectical hydrosocial cycle can be sketched as shown in figure 1.

\section{The French model of river basin authorities}

The French water act of 1964 created six river basin authorities after the German mutualist model of Genossenschaften that had long existed on the Ruhr and the Emscher Rivers, and a combination of British and American experiences of integrated river management. This evolution can be understood as the consequence of a specific moment in the hydrosocial cycle when economists proposed a new definition of pollution, but failed to challenge the social order dominating the French post-war waterscape.

The post-war waterscape was inherited from the Third Republic (1870-1940), which used to govern waters as distinct resources, and regulated them by zones dedicated to specific uses (navigation, power production, irrigation, urban supply, fishing etc.). The discharge of waste 
had been permitted by the government into "sacrificed" rivers from the beginning of the $20^{\text {th }}$ Century onwards (Garcier, 2007; Massard-Guilbaud, 1999). The state would prevent industrialisation near rivers and above aquifers wherever urban water supply was at stake, and would allow industrial waste to accumulate downstream. Sanitation was very poor and consisted only of combined sewers in downtown areas (Guérin-Schneider, 2011; Pezon and Canneva, 2009).

This resulted in a spatial zoning of water uses, limiting irrigation and fishing downstream and restricting the development of cities and industries upstream. Riparian inhabitants would often complain about local damages caused by industrial and urban waste, but most of them received compensation through out-of-court settlements (Fressoz, 2007). There were demands for clean-up operations but not at the national level where water quality was not an issue. The word "pollution" was used very little: only by two different social groups. It served as a technical term for hygienists to describe waters that should not be used for domestic supply. Anglers used the term with a moral connotation to blame waste for killing fish. These fishermen were a real pressure group at national level. They had long fought the issue of pollution through litigation, and had received a substantial amount of compensation. This was what the waterscape looked like in 1959, when political events reopened the ontological question about what water was, or more precisely what pollution was.

In 1959 during the emergency powers, President de Gaulle tried to obtain legitimacy by paying attention to domestic claims. Anglers succeeded in including the issue of river pollution on the political agenda, which resulted in legislation allowing prosecution for discharging waste into rivers in a wider range of circumstances (Bouleau et al., 2009). Industrialists and municipalities asked for more lenient enforcement of these new laws. The prime minister put the existing Commissariat général au Plan in charge of the problem. This central office for planning, also known as the Plan, was specialised in addressing long term 
issues. State engineers and economists of the Plan were dealing with the possible loss of the colonial empire and the consequences of the post-war baby boom. They envisioned a rise in demand for urban water supply and were embarrassed with the new political issue of pollution. They set up a water commission within the Plan in 1959, gathering together several engineers who had worked overseas. Many had "Western attitudes toward arid regions" (Linton, 2010:124) and considered that aridity was a problem. Upon their return to the French waterscape, they were anxious that the poor quality and scarcity of fresh water could threaten the economy (Colson and Cusset, 2005). Their concerns echoed similar ones raised in other parts of the Western world which gave birth to what has been called the second wave of environmentalism (Gottlieb, 2005; White, 1995). Among those who joined the water commission was Hubert Lévy-Lambert, an engineer and economist much inspired by Pigou's work $^{1}$. He translated Kneese's theses into French ${ }^{2}$. He found the problem of pollution a good opportunity to solve the type of puzzles he was trained for: a market-like regulation optimising the allocation of scarce resources. What could possibly be a scarce resource in the French post-war waterscape that was suddenly challenged by the political problem of pollution? Clean water was a good candidate to fit into this abstract category ${ }^{3}$. The government had not previously looked at metropolitan surface water as a whole. Existing atlases dedicated to water were use-specific ${ }^{4}$. According to Kneese's theory, pollution could be conceived as an economic externality reducing the availability of clean water at a river

\footnotetext{
${ }^{1}$ Pigou, A.C., 1920. The Economics of Welfare, 4th edition ed. Mac Millan (1952), Londres.

${ }^{2}$ Kneese, A.V., 1962. Water Pollution: Economic Aspects and Research Needs. Johns Hopkins Press, Baltimore., Kneese, A.V., 1967. Économie et gestion de la qualité des eaux: "the Economics of regional water quality management". Traduit et adapté par H. Hubert Lévy-Lambert. Dunod, Paris.

${ }^{3}$ In 1962, the Plan issued a report listing the resources whose scarcity could threaten the economic development of France by 1985. Clean water is mentioned in pages 127-128 : Guillaumat, H., Krier, M., Bernard, J., Petit, E.C., Demonque, M., Estrangin, L., Fourasquie, J., Jouvenel, B.d., 1962. Réflexions pour 1985. Commissariat général au Plan, Paris.

${ }^{4}$ For drinking purposes see Imbeaux, D., 1931. Annuaire statistique et descriptif des distributions d'eau de France, Algérie, Tunisie et colonies françaises, Belgique, Suisse et Grand-Duché de Luxembourg,, 3ème édition ed. Dunod, Paris.; for waterways see Ecole Nationale des Ponts et Chaussées, Ministère des Travaux Publics, 1899. Atlas des voies navigables de la France. - Navigation de la Seine entre Paris et la mer. Imprimerie Nationale, Paris.; for hydropower see Chambre syndicale des forces hydrauliques de l'électrométallurgie de l'électrochimie et des industries qui s'y rattachent, Société hydrotechnique de France, 1945. Atlas hydroélectrique de France. sd, Paris.
} 
basin level. An ecotax could demonstrate -through the huge amount of initial charges incurred- the scarcity of clean water at this level. However, an ecotax required that water quality objectives be decided for each river basin (Barré and Bower, 1981:138). The water commission of the Plan imagined four categories of water quality to satisfy the existing uses, since they had no intention of improving the quality of the water in every single river.

Anglers had a different perspective. They refused to support a piece of legislation that would officially leave some rivers untreated. They lobbied senators, who were already sceptical about creating organisations whose jurisdiction crossed the pre-existing administrative boundaries. Senators wanted elected officials to keep the power to decide where and when dams or treatment plants would be built. State engineers and prefects were also reluctant to give up some prerogatives to river basin authorities.

The French model drifted away from economic theory and did not challenge either state power or local politicians. Water quality objectives remained at the discretion of administrative officers. Politicians and state officers kept their privileges. A basin committee, bringing together local elected officials, water-users, and state engineers, would set priorities in five-year basin plans. Local authorities initiating projects which complied with the plan could apply for subsidies (from 20 to $50 \%$ of the whole cost) from the river basin authorities. This made the latter very dependent on the willingness of 36,000 municipalities to invest in water facilities.

The establishment of the river basin authorities reshaped the national waterscape. Additional dams and wastewater treatment plants allowed further urbanisation and agricultural intensification. Upstream regions became suitable for new settlements, whereas they were previously protected to secure water supply for downstream cities. Downstream regions whose growth had previously been restricted by state law due to the lack of diluting capacities in the previously "sacrificed" rivers were given new ways of dealing with their 
waste. Alongside this process, the water industry benefited from a significant amount of ringfenced funding, which accumulated in the years since the creation of the river basin authorities. The fees collected by the latter were indeed assigned for use in the water sector, provided they spent it each year. However, like many funding agencies, French river basin authorities had difficulty using up their budget.

The river basin authorities' first plans all had the aim of promoting large multi-purpose reservoirs and industrial waste water treatment plants. The construction of urban municipal treatment plants proved much more difficult. Elected officials were reluctant to invest in depolluting devices, since river pollution was not a widespread concern. Urban inhabitants were instead asking for sewerage, which concentrated pollution as opposed to treating it. Basin committees developed programs to subsidise sewerage whenever municipalities accepted to further invest in sewage treatment. Thus, river basin authorities became involved not only in large infrastructure but in all municipal water services. They played a key role in implementing standardised technologies such as activated sludge treatment processes and combined sewers (for runoff and wastewater) that state engineers promoted at national level. Today public sewers drain $80 \%$ of French domestic wastewater and transport it to treatment plants. River basin authorities funded more than $20 \%$ of the total cost of the equipment through the fees they collected from water users. The amount of fees they collect has regularly increased since then, representing 1.3 billion Euros in 2011.

One thing that was hardly discussed in 1964 was the set of budgetary rules governing river basin authorities. As public bodies under French law, these can not carry over their budget surplus from one year to another. They have to find projects to subsidise according to the amount they have collected each year. In case of excess profits in a given year, the tax office could legitimately cut their budget, and actually did in 2003. River basin authorities are 
therefore quite dependent on local initiatives and local consensus as to which projects are deserving of subsidisation.

Combining hydrology and political economy, French planners conceptualised the circulation of water and capital as a system in which good quality water was a resource for economic development. This system targeted the treatment of urban pollution, with river basin authorities becoming the vehicle for developing sewage treatment plants and sewerage networks in urban waterscapes. This co-production of water science and waterscape is summarised in figure 2. However, each river basin authority soon departed from this common model to develop its own water allocation and management policy.

\section{The Rhône hydrosystem}

The river basin authority in charge of rivers flowing into the Mediterranean Sea is AERMC (Agence de l'Eau Rhône Méditerranée et Corse). Its remit includes the Rhône River, which has a greater number of dams, and whose route encompasses more nuclear power stations than any other river in France (see map 1). Interestingly though, since the 1990s AERMC has been considered as one of the most environmentally-aware river basin authorities. Today, only half of its budget is dedicated to water infrastructure. The other half consists of incentives for ecological restoration and for improving the management of existing infrastructures.

This situation resulted from scientific and political changes in the 1990s, whose origin dated back to the 1970s, when specific circumstances challenged how water had been conceived in the Rhône waterscape. Given the significance of industries and irrigation in the Rhône river basin in the sixties, AERMC originally tackled industrial pollution and low instream flows during the summer. Urban pollution was a secondary issue. AERMC had high hopes, but municipalities were reluctant to invest in wastewater treatment. They considered 
that the Rhône had ample capacity to dilute their urban wastewater. In the late seventies, fees exceeded the amount that the river basin authority actually spent, and the basin committee obtained a corresponding reduction in those fees. AERMC adapted to this constraint by spending less money on each project. The river basin authority would typically cap its funding at $20 \%$ of the total cost of each project. By drip-feeding its subsidies in this way, AERMC was able to impose its policy without depending on a particular municipality to spend its budget. Changes in municipal agendas had little effect on the general budgeting of the basin. Nevertheless, it did not have a great deal of discretion in respect of national stakes. The national use of the Rhône for power production long remained outside the river basin authority's remit.

In 1933, the French Government had set up a publicly-owned company to develop the Rhône River (CNR, Compagnie Nationale du Rhône) for hydropower, irrigation, and navigational purposes. Works only began after World War II thanks to the funding support of the Marshall plan. Huge developments resulted in channelisation, dike rising and damming. Twelve large hydropower stations were built downstream from Lyon (see map 1). The whole project was presented as one of taming the powerful and wild river for the modernisation and independent power production of the nation (Pritchard, 2011). Upstream from Lyon, the undeveloped part of the Rhône was considered less profitable and was used extensively for activities that were no longer possible downstream of the city, such as fishing, hiking, birdwatching and swimming. The upper Rhône was also an escape from urban life for many Lyon residents. Moreover, this place was a haven for floodplain vegetation and river invertebrates. The natural science lab in the University of Lyon had excellent specialists in these taxa. The dynamic upper Rhône and its tributaries were prime locations for observing these creatures, as opposed for instance to the downstream part of the Rhône whose dams and canals reduced the floodplain. 
Things changed after the first oil crisis in 1973. The government issued electric heating system standards for dwellings in order to reduce the use of oil. As a result of this, developing the upper Rhône for power generation became profitable. The government boosted the nuclear program for civil purposes (Hecht, 1998). Six nuclear plants were built on the Rhône. Similarly, the state sought new sites for hydropower production, and it gave CNR the concession to operate in the upper part of the Rhône, between the Swiss border and Lyon. The 1970s were a different era from that of the Marshall plan, and human affairs ran a different course. Ecologists and antinuclear activists opposed the development of the upper Rhône from 1975 to 1985 (Michelot, 1990).

Philippe Lebreton, a researcher at the University of Lyon's natural science department, was also a keen bird-watcher and environmental activist. He brought together ecologist associations in the Rhône-Alpes region with a few colleagues in 1970. Trained as a biochemist, he also taught plant physiology and ecology (Mauz, 2011). Drawing on his dual experience, he was able to convert the concerns of environmentalists about development in the upper Rhône area into a subject of legitimate ecological research. He had different ideas for shaping a "puzzle" (Kuhn, 1963). In 1973-74, he had supervised a geomorphological study aimed at mapping the evolution of the Rhône meanders from the Middle Ages in the upstream region of Lyon: an area where the CNR had already planned to build a dam, and which had not been considered profitable before the oil crisis. The study could be taken as a reference state. CNR developments would probably further reduce the geomorphological dynamics of the river, and affect the spatial distribution of many taxa. Funding for such research was however limited.

In the late seventies, the second-wave environmental movement reached the top echelons of French government. In 1976, a law was enacted requiring ecological impact assessment prior to the construction of large developments, which had to be carried out at a company's 
own expense. CNR had to comply with the new rules, and was therefore willing to pay for flora and fauna inventories before and after the construction of each dam. The University of Lyon set up a not-for-profit consultancy dedicated to this task, the data from which were later compiled in the natural science laboratory for theoretical generalisation. The Ministry of Environment and the National Research Centre (CNRS, Centre National de Recherche Scientifique) did not directly engage with the nuclear and hydropower programs, but jointly proposed interdisciplinary research grants (PIREN, programme interdisciplinaire de recherche sur l'environnement) to study the environmental functioning of large rivers by combining different disciplines.

Lebreton and his colleagues jumped at the opportunity to publicise their studies of ecological impacts of dam-building among the national and international scientific community. Albert-Louis Roux, who set up the PIREN Rhône research proposal, was a specialist in Gammaridae, which are macro-invertebrates living in well oxygenated rivers. The project attracted other scientists interested in floodplain evolution and the corresponding spatial distribution of habitats. Since the ecological concept of habitat does not apply to phyto and zooplankton, few specialists of these taxa took part. There was also no participation from specialists in trophic transfers. Given the diversity of habitats in the Upper Rhône, assessing the global budget of nutrients was a difficult task to complete. The Upper Rhône became a site of interest for ambitious geographers looking for physical and human changes to observe. 


\begin{tabular}{|c|c|c|c|}
\hline \multirow{2}{*}{\multicolumn{2}{|c|}{$\begin{array}{l}\text { Discipline (assessed from publications) } \\
\text { before joining the PIREN }\end{array}$}} & PIREN Rhône & PIREN Seine \\
\hline & & $(1980-1990)$ & $(1990-2000)$ \\
\hline \multicolumn{2}{|c|}{ Physical Geography } & 3 & 0 \\
\hline \multicolumn{2}{|c|}{ Human Geography } & 2 & 0 \\
\hline \multicolumn{2}{|c|}{ Engineering } & 0 & 4 \\
\hline \multicolumn{2}{|c|}{ Geochemistry } & 0 & 1 \\
\hline \multicolumn{2}{|c|}{ Biological Computer Science } & 1 & 0 \\
\hline \multicolumn{2}{|c|}{ Hydrology } & 0 & 3 \\
\hline \multicolumn{4}{|c|}{ Ecology, with a specialisation on } \\
\hline \multicolumn{2}{|c|}{\begin{tabular}{l|l|} 
Fish
\end{tabular}} & 1 & 2 \\
\hline \multicolumn{2}{|c|}{ Macro Invertebrates } & 2 & 0 \\
\hline \multicolumn{2}{|r|}{ Phytoplankton } & 0 & 1 \\
\hline \multicolumn{2}{|r|}{ Zooplankton } & 1 & 3 \\
\hline \multicolumn{2}{|r|}{ Phytosociology } & 1 & 0 \\
\hline \multicolumn{2}{|r|}{ Forest } & 1 & 0 \\
\hline \multicolumn{2}{|r|}{ Trophic transfers in general } & 0 & 5 \\
\hline \multicolumn{2}{|c|}{ Biostatistics } & 2 & 0 \\
\hline total & & 14 & 19 \\
\hline
\end{tabular}

Table 1 : Composition of the research teams who worked in the Rhône and Seine PIREN project.

Within the new research initiative, natural scientists monitored river bed movements. They translated them into the hydrosystem concept, which links hydrologic and ecological processes not only along the river continuum, but also along the width and depth of the floodplain (Amoros and Petts, 1993; Amoros et al., 1987; Roux, 1982). Floods, they showed, were necessary to maintain the ecological functioning of the river in relation to groundwater. Dams would hinder the mobility of the river bed. They would lessen groundwater recharge 
and floodplain biodiversity. The interdisciplinary research project resulted in a claim that large instream flows should be maintained.

This claim was then voiced by ecological activists. In 1984, they eventually managed to have the Ain-Rhône confluence classified as a natural reserve with a significant compulsory instream flow, which made the prospect of a dam unprofitable for the CNR. The last hydropower dam planned by the CNR was never built (Pritchard, 2001). This political success of ecologists on the Rhône, coupled with similar successes on the Loire River, strengthened their position at national level. The then Environment Minister Brice Lalonde (1988-1992) undertook public hearings on water in 1990 and 1991. The water law of 1992 established new licensing procedures for projects likely to affect aquatic ecosystems and wetlands.

Such changes in national policy shook the AERMC committees. Albert-Louis Roux became president of the river basin executive committee in 1994. He promoted the concept of hydrosystem in the making of the river basin masterplan of $1996\left(\mathrm{SDAGE}^{5}\right)$. Several former students of the natural science laboratory in Lyon found jobs in AERMC. Dam building and dike rising that once represented modernity lost their appeal in the Rhône area. The investment doctrine of AERMC changed from one of waste water treatment and multipurpose dam-building to one of river restoration.

\section{The Seine bioreactor}

The Seine waterscape is not one of Gammaridae. The slow-flowing, rigidly-channelled tributaries of the Seine harboured a much less diverse range of species than those of the Rhône. The Seine River has never been concerned with dam-building either. The river basin authority in charge of the Seine River and coastal rivers of Normandy is AESN (Agence de

\footnotetext{
${ }^{5}$ Schéma Directeur d'Aménagement et de Gestion des Eaux.
} 
l'Eau Seine Normandie). It is a small river compared to the Rhône whose average discharge is five times higher. It flows through France's largest and richest metropolis, Paris. AESN is consequently the wealthiest river basin authority. As originally pointed out by geographer Jean-François Gravier (1947), the French capital had grown at the expense of the rest of the country. This argument justified several planning policies aimed at developing other economic centres in the provinces. The primacy given to the capital nevertheless remained, and Gravier's book title somehow naturalised the dichotomy between "Paris and the French desert".

The growth of the Greater Paris region relates to places of power. Municipal and intermunicipal constituencies around the capital are seats for national political careers. Wellknown elected officials of the region did not need AESN support in developing urban water infrastructure that was profitable in densely populated areas. They contested the usefulness of the organisation and were reluctant to pay fees. The first directors of AESN intended to quell hostilities by offering significant financial aid. They struggled to maintain a high level of water fees and corresponding subsidies that amounted to $40 \%$ of the total cost of each individual project. Although large cities did not need such funding they found it attractive. AESN became dependent on large projects. Whenever one stopped, AESN could have trouble in shifting the corresponding amount to another project, and the budget surplus was always at risk of being reclaimed by the state. Employees of AESN consequently developed a sense of duty that encompassed the ability to rapidly spend large amounts of funds (Bouleau, 2007; Narcy, 2000). The modernisation of the Paris wastewater treatment plant was the perfect project in this regard.

Council-employed technicians in Paris and surrounding towns did not wait for the AESN to draw up water management plans. They were proud of the hundred-year-old sewerage 
system, which collected waste water from Greater Paris and conveyed it by gravity to Achères (see map 1).

The river basin authority agreed to fund the actions set out in this water plan, whereby waste water would continue to be directed to Achères, transforming it into one of the largest waste water treatment plants in Europe. The concentration of treated urban waste into a single point of the Seine River resulted in very poor water quality, not only downstream from Paris, but up to the estuary in Rouen. Despite continuous complaints from residents along the banks of the river, the managers of Achères intended to triple the plant's capacity in 1989. AESN allocated funding to cover $40 \%$ of the total cost of this expansion, and raised fees collected from local residents accordingly. The government encouraged the fee rise, anticipating the European urban wastewater directive, which would impose more stringent standards of treatment. But the course of human affairs was going to disturb the designed wastewater flow.

Prime Minister Rocard (1988-1991), former mayor of a city close to Achères, opposed the growth of this particular plant. One third of the total budget AESN had put by for the coming five-year plan got stuck. Two thirds of Greater Paris's wastewaters flowed untreated into the Seine. The state administration in charge of water licensing translated the problem into one of research, and found a research team interested in the topic, who could apply for funding to the PIREN program.

Scientists' motivation to study the Seine was very different from their counterparts on the Rhône. Researchers joining the project had no ties with activism and wanted to gather together big names in Parisian politics on a scientific basis. They were fascinated by the Great city and its stakes. They enjoyed the intellectual life of the capital and were eager to engage in operational research. Their problem-solving orientation advocated a modelling approach, whose mathematical language and experimental testing was compatible with most of their 
disciplines (see table 1). Aside from the funding from the CNRS and the Ministry of the Environment, the PIREN-Seine project drew upon support from water managers.

Ghislain de Marsily, who originally led the PIREN-Seine project, was an engineer. He audited several research teams to select partners whose research could contribute to the model. A research team in psychology was investigating the collective unconscious of Parisians with regard to water. De Marsily did not consider that they could solve any puzzle for water managers. And so Parisians remained collectively unaware that they were represented as a fixed amount of pollution in the conceptualisation of the Seine River. PIREN-Seine researchers were interested in pollution, dilution, anoxia and eutrophication -the process of algae bloom due to excess nitrate and phosphorus inputs in water. The single course the Seine River made trophic transfer measurement easier than on the Rhône. They negotiated with water managers which elements should be in the model, and understood the functioning of the Seine River as one of a series of bioreactors which broke organic matter down into different forms of carbon, nitrogen, and phosphorous. However, such broad categories failed to account for some empirical observations of the Seine River.

PIREN-Seine researchers initially took into account a single category of algae. However the model was not able to correctly predict algae blooms and corresponding cases of anoxia without making a distinction for diatoms, whose development is controlled by silicium concentration in water ${ }^{6}$. Diatoms, the water managers agreed, deserved a particular category. Similarly the model did not initially pay attention to wetlands. However, researchers could not close the nitrate balance within the hydrologic cycle. They had to recognise that wetlands upstream from Paris transformed huge amounts of nitrates into nitrogen that evaporated. Understood as the equivalent of a denitrification plant, previously ignored, and left aside for future urbanisation, wetlands became something worth modelling.

\footnotetext{
${ }^{6}$ Diatom skeleton is made of silicium
} 
Modelling accounted for the cumulative effects of pollution from waste and cleaning efforts in relation to the location of outlets and treatment plants. It produced evidence that the main factor responsible for anoxia downstream from Paris was the discharge of ammonia from Achères, whose transformation into nitrites and nitrates consumed all the dissolved oxygen contained in the river up to Rouen. No oxygen was left for self-purification of any other forms of pollution.

Modelling was the perfect tool to redeploy treatment facilities away from Achères and to compare different options. It gave AESN its own standpoint and established its credibility on the river basin based on the significance of the ammonia issue. The authority found justification in PIREN Seine to invest in the treatment of ammonia at Achères, to fund two waste water treatment plants upstream from Paris, and to postpone the issue of excess nitrates, which had little effect on the river compared with ammonia, but whose impact in the North Sea had long been on the international agenda.

5. Analysis and discussion: the mutual shaping of waterscapes and science

The three cases presented above provide ample illustration of the hydrosocial cycle which continuously transforms the socionatures constituting a river basin. The co-production of science and social order may be part of this hydrosocial cycle in a process which can be divided into three stages: (1) The scientists saw waterscapes according to their professional and non-professional practices; (2) science production and social change redefined categories used to describe waterscapes; (3) the new categories affected water policies, water uses, and waterscapes. However, as the creation of river basin authorities shows, the hydrosocial cycle and the waterscape may evolve without changing either water science or social order.

5.1 Scientific disciplines and funding opportunities had a "framing" effect on waterscapes 
River basins contain an abundance of different socionatures, from fish selected by fishermen to harbours wiped out by floods. The concept of the hydrosocial cycle grasps the dynamic process through which such socionatures are continuously reworked as society and water continue to develop, each depending on the other. Waterscapes are time-specific images of this process, interpreted in relation to the observer's practice. The professional practices of PIREN researchers made sense of the Rhône and the Seine waterscapes in relation to their scientific disciplines, and how theses basins could be "put to task" (Rose, 2002), i.e. used as the basis for revealing a puzzle and finding a solution.

The Seine waterscape did not present a topic of any significant interest to geomorphologists, due to the longstanding presence of man-made embankments. In addition to this, the key issues at that time (namely wastewater treatment) were outside of their field. Such elements made more sense, and offered more professional opportunities for ecologists interested in trophic transfers. River scientists involved in PIREN Seine and PIREN Rhône saw the waterscape they were interested in seeing, i.e. the river that carried elements they were taught to analyse within their respective areas of expertise. Engineer de Marsily was interested in producing a model that would be of some use to municipal water services. Freshwater biologist Roux saw invertebrates as sentinel species threatened by river development. Both were attracted to the river that flowed through the city where they had chosen to live and study. When setting up an interdisciplinary project aimed at conceptualising a whole watershed, they could not ignore powerful water users. Their encounter with the river was mediated by the waterscape. They practised self-censorship to avoid subjects they perceived as overly controversial. In this way, Roux and his team did not 
want to address nuclear power, whose effect on temperature nevertheless proved significant in summer $2003^{7}$.

Researchers accounted for specific singularities of the river that resulted from history and discarded others. De Marsily and his colleagues did not consider the presence of particular species in the Seine river, but took the Achères outlet as a given. Some elements of waterscapes are also treated this way by scientists, for example they do not question the appropriation of water (Budds, 2009), or the specificities they were attracted to in these waterscapes. However, scientists may also scrutinise pre-existing categories.

5.2 Science and politics changed the categories used to make sense of waterscapes

Landscapes are constituted by "immanent possibilities inspiring things to happen" and by the "devices humans invent to hold onto a world that always overwhelms their grasp" (Rose, 2002:461). The development of science and political mobilisations challenge the elements that make up cognitive frameworks, such as the relevant scale and the categories describing socionatures.

Cognitive frameworks embedded in waterscapes are based on specific scales. Before the PIREN Rhône research started, the Rhône waterscape was seen through the lens of the nation. Dam-building was heralded as a modern endeavour that would secure growth and independence of power production. CNR was trusted to develop water resources and allocate benefits between the nation and the region. Activism and science were two forms of agency that challenged this national framing, in favour of a more Upper Rhone-specific scale. At the same time, the PIREN Seine, along with opponents of the growth of Achères, challenged the centrality of Achères in the Seine waterscape. The framework centred on Achères shifted in order to encompass sites located further upstream.

\footnotetext{
${ }^{7}$ During the 2003 heat wave, the Rhône water temperature raised. Environmental authorities required that some nuclear reactors be stopped to prevent further warming of the water.
} 
Such changes in scale are related to changes in categories of socionature. The scientists I interviewed conceptualised water through pre-existing categories (organic matter, nitrogen, fish, or macro-invertebrates) and pre-established processes (including nitrates causing eutrophication and consuming dissolved oxygen). Yet, in the process of research, they recast equivalences and differences, causalities and determinisms. The PIREN Seine distinguished diatoms from other algae to account for the control of algae blooms by silicium in the Seine. This might not be the case in all rivers, but the current waterscape of the Seine is one in which silicium sometimes matters. Furthermore, scientists also reaffirmed some pre-existing categories. The distinction between the Upper Rhône and the lower Rhône had existed in the CNR-based waterscape when the profitability in terms of power production was lower upstream, but the distinction faded with the oil crisis. Residents of Lyon experienced this dichotomy in their leisure time, and scientists experienced it when collecting invertebrates. They translated this dichotomy into an abstract language, using the number of existing taxonomic categories.

When scientists broke a category down into two different entities in spite of Ockham's razor rule, they highlighted certain spatial differences. It enabled political mobilisation in favour of maintaining these differences. The distinction between the upper and lower Rhone based on biodiversity proved to be influential in challenging the previously well-accepted practice of building dams along the Rhône.

In parallel, some scientists commensurated groups of elements, previously considered separately, into new categories. Discourse using these broader categories tended to disable the actors who still saw each element separately. When the Seine bioreactor model revealed that the most significant impact of Achères on water quality was not due to nitrates but ammonia release, which consumed dissolved oxygen as far downstream as Rouen, the focus on ammonia all but silenced nitrate-related issues. Riparian forests, marshes, and swamps, whose 
functions explained the reduction of the input of nitrate into the river, received less attention, and were grouped into one single "wetlands" category. With PIREN Seine, swamps were no longer considered on an individual basis. In the PIREN Rhône project, however, wetlands were divided according to their vegetation, to map the threat that dams posed to each of them.

\subsection{New categories transformed politics and, by consequence waterscapes}

As water science evolves, it might change the social and political order giving rise to the dominant framing (Jasanoff, 2004). Before the PIREN Seine started, stakeholders in water management had little idea of the extent to which they could be held responsible for the production of ammonia, nitrates, phosphorous, organic matter, and algae at the watershed level. They were interested in the possibility of results showing that they were not responsible for the lion's share of pollution. They agreed to make their data available to researchers, and to finance the research project in order to modify their justifications for funding according to a changing array of problems. Results unexpectedly weakened the positions of those asking for funding to carry out nitrate removal, as well as discrediting proponents of Achères, who did not consider any other site for treating Parisian waste waters. By reconfiguring socionatures in a different way, scientists remodelled spaces of equivalence (Desrosières, 1998:50). Before the advent of PIREN Seine, the wastewater treatment plant of Achères had no equivalent. Modelling the Seine River as a series of bioreactors created a space of equivalence at the basin scale for several possible treatment plants. As Desrosières argued, "the faculty of conceiving" encompassing categories is connected to the "possibility of occupying such overlooking positions" (Desrosières, 2000:66, translation of the author). The hydrologic boundaries of the PIREN Seine model made sense for AESN. The model created an opportunity to redeploy treatment capacities along the river, thus reallocating certain responsibilities. It changed the remit of the river basin authority and the way it perceived its role. It changed its funding policy, which in turn changed the development of the waterscape. 
Similarly, municipal water services felt at ease with representing inhabitants using a fixed amount of pollution within the Seine model, even if it obscured the individual behaviour of residents, because it also erased the inhabitants' own agency to the benefit of water managers. However such representation prevents us from imagining a different pattern of water consumption by inhabitant.

\section{Conclusion}

The distinct categories available to describe the environment enable actors to express some spatial and temporal differences, while they obscure the differences between elements designated by the same word. Categories are taught in school, used in management, and disputed in politics. They are vehicles for stating what matters and what does not in different situations. Traditionally, the social theory considers that such discursive categories only exist in the realm of culture. The hydrosocial cycle concept departs from this tradition in considering that ways of speaking about water and what water is are co-produced dialectically. This process builds in a cognitive framework, albeit temporary. The cases of PIREN Seine and PIREN Rhône suggest that this framework also affects the construction of water science, because waterscapes do not interest all scientists in the same way. However, whereas scientists investigate in a specific waterscape, they select some categories as relevant, create new ones, and ignore others, in relation with current social and political issues. The coproduction of science and social order result in both new spaces of equivalence and hierarchy of interest. The whole process gradually changes waterscapes, both materially and conceptually, without determinisms.

Figures and maps

<insert Map 1> 
Map 1. The Rhône and the Seine river basin authorities (map created by Daniel Uny, Cemagref Bordeaux, France)

<insert figure 1>

Figure 1: The hydrosocial cycle co-producing science and the waterscape: a cycle of reopening and closing off the ontological question of what water is, and the normative question of what the waterscape should be. (Source: author).

<insert figure 2>

Figure 2: The hydrosocial cycle having failed to co-produce knowledge and waterscapes in France (1959-1970). Pollution was not redefined as an environmental externality, but rearticulated to existing routines in order to develop a dams, sewerage and wastewater treatment plants funded by the fees collected by river basin authorities. (Source: author).

<insert figure 3>

Figure 3: The hydrosocial cycle having co-produced knowledge and waterscapes in the Rhône river basin (1979-1992). Ecological knowledge about the floodplain and its dynamic geomorphology serves to justify large instream flows and wetland protection. (Source: author).

<insert figure 4>

Figure 4: The hydrosocial cycle having co-produced knowledge and waterscapes in the Seine river basin (1989-2000). The bioreactors model challenged the centrality of Achères and helped to reallocate wastewater treatment facilities to address ammonia issues as a priority (Source: author).

References 
Agnew, J., 1987. Place and politics. The geographical mediation of state and society. Allen \& Unwin, Boston.

Alatout, S., 2008. 'States' of scarcity: water, space, and identity politics in Israel, 1948 - 59. Environment and Planning D 26, 959 - 982.

Amoros, C., Petts, G.E., 1993. Hydrosystèmes fluviaux. Masson, Paris.

Amoros, C., Roux, A.L., Reygrobellet, J.L., Bravard, J.P., Pautou, G., 1987. A method for applied ecological studies of fluvial hydrosystems Regulated Rivers 1 (1), 17-36.

Bakker, K., 2003a. An Uncooperative Commodity: Privatizing Water in England and Wales. Oxford University Press, Oxford.

Bakker, K.J., 2003b. A political ecology of water privatization. Studies in Political Economy (70), 35-58.

Barré, R., Bower, B.T., 1981. Water management in France, with special emphasis on water quality management and effluent charges, in: Bower, B.T., Barré, R., Kühner, J., Russel, C.S. (Eds.), Incentives in Water Quality Management - France and the Ruhr Area. Resources for the Future - distributed by the Johns Hopkins University Press Baltimore Maryland, Washington, pp. 33-209.

Bouleau, G., 2007. La gestion française des rivières et ses indicateurs à l'épreuve de la directive cadre., Sciences de l'environnement. AgroParisTech - ENGREF, Paris, p. 457.

Bouleau, G., Argillier, C., Souchon, Y., Barthélémy, C., Babut, M., 2009. How ecological indicators construction reveals social changes - the case of lakes and rivers in France. Ecological Indicators 9 (6), 1198-1205.

Bowker, G.C., Star, S.L., 1999. Sorting Things Out. Classification and Its Consequences. MIT Press, Cambridge, Massachusetts. 
Budds, J., 2008. Whose scarcity? The hydrosocial cycle and the changing waterscape of La Ligua River Basin, Chile. , in: Goodman, M., Boykoff, M., Evered, K. (Eds.), Contentious Geographies: Environmental Knowledge, Meaning, Scale, pp. 59-78.

Budds, J., 2009. Contested H2O: science, policy and politics in water resources management in Chile Geoforum (40), 418-430.

Chambre syndicale des forces hydrauliques de l'électrométallurgie de l'électrochimie et des industries qui s'y rattachent, Société hydrotechnique de France, 1945. Atlas hydroélectrique de France. sd, Paris.

Colson, A., Cusset, P.-Y., 2005. Revisiting a futures studies project--'Reflections on 1985'. Futures 37 (10), 1057-1065.

Desrosières, A., 1998. The Politics of Large Numbers. A History of Statistical Reasoning. Harvard University Press. , Cambridge, Ma.

Desrosières, A., 2000. La politique des grands nombres. Histoire de la raison statistique. La découverte Poche, Paris.

Douglas, M., 1986. How institutions think. Syracuse University Press, Syracuse, New York. Ecole Nationale des Ponts et Chaussées, Ministère des Travaux Publics, 1899. Atlas des voies navigables de la France. - Navigation de la Seine entre Paris et la mer. Imprimerie Nationale, Paris.

Espeland, W.N., 1998. The struggle for water: politics, rationality, and identity in the American southwest. University of Chicago press, Chicago.

Fressoz, J.-B., 2007. Beck Back in the 19th Century: Towards a Genealogy of Risk Society. History and Technology 23 (4), 333-350.

Garcier, c., 2007. Rivers we can't bring ourselves to clean - historical insights into the pollution of the Moselle River (France), 1850-2000. Hydrol. Earth Syst. Sci. Discuss. (4), $1697-1727$. 
Gille, Z., 2006. Detached Flows or Grounded Place-Making Projects, in: Spaargaren, G., Mol, A.P.J., Buttel, F.H. (Eds.), Governing environmental flows. Global challenges to social theory. MIT Press, Cambridge, MA, pp. 137-156.

Goffman, E., 1967. Presentation of self in everyday life.

Goffman, E., 1974. Frame Analysis: An essay on the organization of experience.

Gottlieb, R., 2005. Forcing the Spring: The Transformation of the American Environmental Movement. Island Press, Washington.

Gravier, J.-F., 1947. Paris et le désert français. Le Portulan.

Guérin-Schneider, L., 2011. Histoires des services publics d'eau potable et d'assainissement : entre stabilité et reconfiguration, in: Bouleau, G., Guérin-Schneider, L. (Eds.), Des tuyaux et des hommes: l'eau en réseaux en France. collection Indisciplines, Quae, Paris.

Guillaumat, H., Krier, M., Bernard, J., Petit, E.C., Demonque, M., Estrangin, L., Fourasquie, J., Jouvenel, B.d., 1962. Réflexions pour 1985. Commissariat général au Plan, Paris.

Haraway, D., 1990. A manifesto for cyborgs. Science, technology and socialist-feminism in the late 1980's, in: Nicholson, L.J. (Ed.), Feminism/postmodernism. Routledge, New York. Hecht, G., 1998. The Radiance of France: Nuclear Power and National Identity after World War II. MIT Press.

Imbeaux, D., 1931. Annuaire statistique et descriptif des distributions d'eau de France, Algérie, Tunisie et colonies françaises, Belgique, Suisse et Grand-Duché de Luxembourg,, 3ème édition ed. Dunod, Paris.

Jasanoff, S., 2004. States of Knowledge. The co-production of science and social order. Routledge, p. 317.

Jasanoff, S., 2010. A New Climate for Society. Theory, Culture \& Society 27 (2-3), 233-253.

Kaika, M., 2005. City of Flows: Modernity, Nature, and the City. Routledge, London and New York. 
Kneese, A.V., 1962. Water Pollution: Economic Aspects and Research Needs. Johns Hopkins Press, Baltimore.

Kneese, A.V., 1967. Économie et gestion de la qualité des eaux: "the Economics of regional water quality management". Traduit et adapté par H. Hubert Lévy-Lambert. Dunod, Paris.

Kuhn, T.S., 1963. The Structure of Scientific Revolutions. University of Chicago Press, Chicago.

Latour, B., 1993. We have never been modern. Harvard University Press.

Linton, J., 2008. Is the Hydrologic Cycle Sustainable? A Historical-Geographical Critique of a Modern Concept. Annals of the Association of American Geographers 98 (3), 630-649.

Linton, J., 2010. What is water. UBC press, Vancouver.

Massard-Guilbaud, G., 1999. La régulation des nuisances industrielles (1800-1940). Vingtième Siècle. Revue d'histoire (64), 53-66.

Mauz, I., 2011. Biographie de Philippe Alain Jean Lebreton, Biographies de personnalités. Association pour une histoire de la protection de la nature et de l'environnement. Association pour une histoire de la protection de la nature et de l'environnement.

Michelot, J.-L., 1990. Les conflits pour l'aménagement de l'espace au confluent Ain-Rhône. Annales de géographie XCIX (555), 527.

Narcy, J.-B., 2000. Les conditions d'une gestion spatiale de l'eau, Sciences de l'environnement. ENGREF, Paris, p. 488.

Pezon, C., Canneva, G., 2009. Petites communes et opérateurs privés : généalogie du modèle français de gestion des services d'eau potable. Espaces et sociétés (139).

Pigou, A.C., 1920. The Economics of Welfare, 4th edition ed. Mac Millan (1952), Londres. Pritchard, S.B., 2001. Was hydroelectric development an ecological choice in post World War II France?, in: Frankel, B., Allison, R.J., Showalter, D.E. (Eds.), History in Dispute: Water and the environment since 1945 : global perspectives pp. 92-95. 
Pritchard, S.B., 2011. Confluence. The Nature of Technology and the Remaking of the Rhône. Harvard University Press, Cambridge, MA.

Rodríguez-Fernández, J.L., 1999. Ockham's razor. Endeavour 23 (3), 121-125.

Rose, M., 2002. Landscape and labyrinths. Geoforum 33 (4), 455-467.

Roux, A.-L., 1982. Cartographie polythématique appliquée à la gestion écologique des eaux. Etude d'un hydrosytème fluvial : le Haut-Rhône français. PIREN CNRS, Paris.

Steinberg, P.E., Clark, G.E., 1999. Troubled water? Acquiescence, conflict, and the politics of place in watershed management Political Geography 18 (4), 477-508.

Swyngedouw, E., 1999. Modernity and hybridity: nature, regeneracionismo, and the production of the Spanish waterscape, 1890-1930. . Annals of the Association of American Geographers 89 (3), 443-465.

Swyngedouw, E., 2004. Social Power and the Urbanization of Water: Flows of Power. Oxford University Press, Oxford.

Taylor, P.J., 1999. Places, spaces, and Macy's: place - space tensions in the political geographies of modernities. Progress in Human Geography 23 (1), 7-26.

Thompson, C., 2004. Co-producing CITES and the African elephant, in: Jasanoff, S. (Ed.), States of Knowledge. The co-production of science and social order. Routledge, p. 317.

Trottier, J., Fernandez, S., 2010. Canals spawn dams ? Exploring the filiation of hydraulic infrastructure. Environment and History 16 (1), 97-123.

White, R., 1995. The Organic Machine. Hill \& Wang, New York.

Worster, D., 1992. Rivers of Empire: Water, Aridity, and the Growth of the American West. Pantheon Books, New York. 